\title{
3-Pyridylacetonitrile-ligated 11-Vertex Rhodathiaboranes: Synthesis, Characterization and X-ray Crystal Structure
}

\author{
B. CALVO ${ }^{\text {a }}$, M. KE $\beta$, R. MACIAS ${ }^{* a}$, R. SANCHO ${ }^{\text {a }}$, F.J. LAHOZ ${ }^{\text {a }} \&$ L.A. ORO ${ }^{* a b}$
}

\author{
a Departamento de Química Inorgánica, Instituto de Síntesis Química \\ y Catálisis Homogénea (ISQCH) (Universidad de Zaragoza-CSIC), \\ Zaragoza, Spain
}

${ }^{\mathrm{b}}$ Center of Research Excellence in Refining \& Petrochemicals King Fahd University of Petroleum \& Minerals, Dhahran, 31261, Saudi Arabia

Dedicated to Prof. Juan Costamagna, a superb mentor of a large number of Latin

American scientists working on coordination chemistry.

Received $x x x$; accepted $x x x$

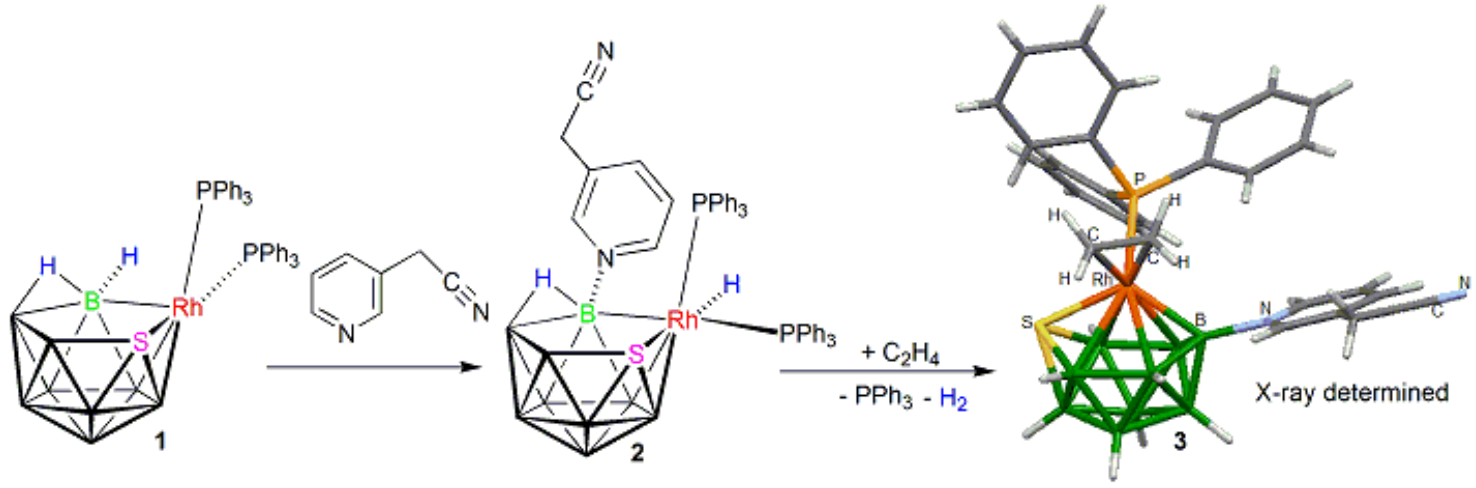

Abstract: The reaction between the 11-vertex rhodathiaborane [8,8- $\left(\mathrm{PPh}_{3}\right)_{2}$-nido-8,7- $\left.\mathrm{RhSB}_{9} \mathrm{H}_{10}\right](\mathbf{1})$ and 3-pyridylacetonitrile affords the hydrorhodathiaborane [8,8,8- $\left(\mathrm{PPh}_{3}\right)_{2} \mathrm{H}-9-\left(3-\mathrm{Py}-\mathrm{CH}_{2} \mathrm{CN}\right)-$ nido-8,7$\mathrm{RhSB}_{9} \mathrm{H}_{9}$ ] (2) in good yield. Treatment of this cluster with ethylene leads to the formation of red, [1,1$\left(\mathrm{PPh}_{3}\right)\left(\eta^{2}-\mathrm{C}_{2} \mathrm{H}_{4}\right)-3-\left(3-\mathrm{Py}-\mathrm{CH}_{2} \mathrm{CN}\right)-$ closo-1,2-RhSB $\left.\mathrm{H}_{8}\right]$ (3). Both 11-vertex polyhedral boron-based clusters have been characterized by multielement NMR spectroscopy. In addition, compound $\mathbf{3}$ has been analyzed by single-crystal X-ray diffraction analysis, and is only the second ethylene ligated metallaheteroborane to be characterized in the solid state. The molecular structure of this cluster is based on an octadecahedron. In the crystal lattice, the individual clusters form layers supported by short edgeto-face $\pi$-interactions between the phenyl rings of neighboring molecules.

Keywords: polyhedral clusters, rhodathiaboranes, ethylene, boron, rhodium 


\section{Introduction}

Metallaheteroboranes are polyhedral boron-based clusters that feature $\mathrm{M}-\mathrm{B}, \mathrm{E}-\mathrm{B}$ and B-B bonds, where $\mathrm{M}$ and $\mathrm{E}$ are metallic and $p$-block elements, respectively. Metallacarboranes, where $\mathrm{E}=\mathrm{C}$, form the largest group of metallaheteroboranes for which a systematic study of their reaction chemistry has been carried out [1-13]. In contrast, the reaction chemistry of other metallaheteroboranes is poorly developed [1420].

The high-yield synthesis of the 11-vertex [8,8- $\left(\mathrm{PPh}_{3}\right)_{2}$-nido-8,7- $\mathrm{RhSB}_{9} \mathrm{H}_{10}$ ] (1) [21] from the reaction of the Wilkinson's compound with $\mathrm{CsSB}_{9} \mathrm{H}_{12}$ has allowed the development of a systematic chemistry based on this cluster. During our research dealing with 1, we have discovered that the reaction with pyridine affords the hydridorhodathiaborane, $\quad\left[8,8,8-\left(\mathrm{PPh}_{3}\right)_{2} \mathrm{H}-9-\left(\mathrm{NC}_{5} \mathrm{H}_{5}\right)-\right.$ nido-8,7- $\left.\mathrm{RhSB}_{9} \mathrm{H}_{9}\right] . \quad$ This 11vertex cluster exhibits a remarkable structural nido-to-closo flexibility that has led to a rich reaction chemistry that embraces: (i) nido-to-closo dehydrogenations [22], (ii) dihydrogen promoted closo-to-nido transformations [23, 24], (iii) oxidative addition of sp C-H bonds, [25] (iv) proton-assisted $\mathrm{H}_{2}$ activation [26] and (v) catalysis of hydrogenation and isomerization of olefins [23]. 


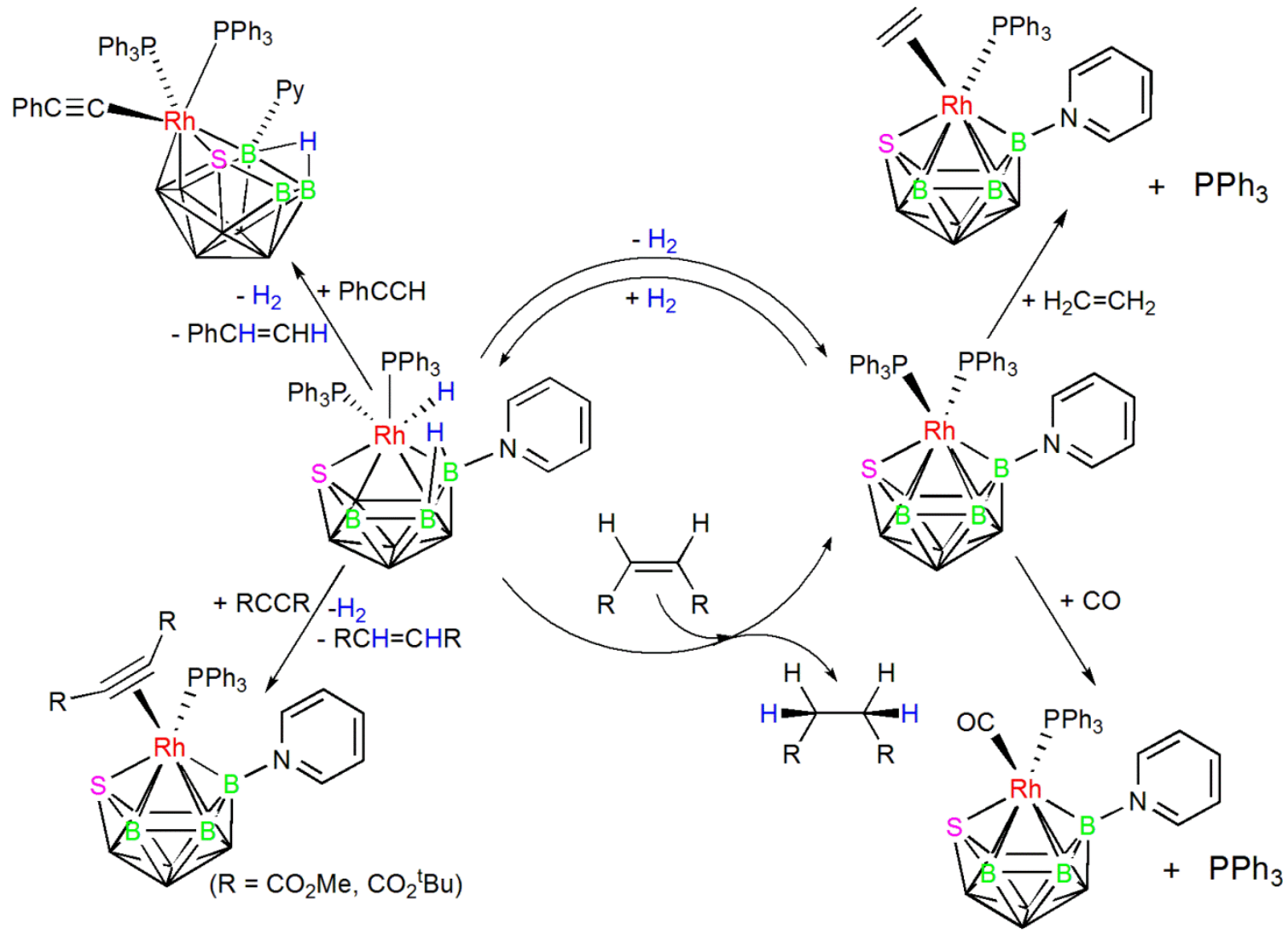

Scheme 1 Some reactions of $\left[8,8,8-\left(\mathrm{PPh}_{3}\right)_{2} \mathrm{H}-9-\left(\mathrm{NC}_{5} \mathrm{H}_{5}\right)-\right.$ nido-8,7- $\left.\mathrm{RhSB}_{9} \mathrm{H}_{9}\right]$

Based on these results, and in order to modify the exo-polyhedral surface of the clusters, we report the reaction of the parent rhodathiaborane 1 with 3-pyridylacetonitrile. The incorporation of a hemilabile ligand such as nitrile has afforded species with a daggling $\mathrm{C} \equiv \mathrm{N}$ coordinating moiety that has a potential to coordinate to the rhodium centre in an intramolecular fashion or, alternatively, to coordinate intermolecularly to form bimetallic species. These modes of coordination may improve the catalytic activity of this type of 11-verter clusters through the stabilization of new intermediates that may perform better than the previously studied systems in, for example, hydrogenation of olefins [22].

\section{Results and discussion}

The reaction of $\left[8,8-\left(\mathrm{PPh}_{3}\right)_{2}\right.$-nido-8,7- $\left.\mathrm{RhSB}_{9} \mathrm{H}_{10}\right]$ (1) with 3-pyridineacetonitrile (3-Py$\mathrm{CH}_{2} \mathrm{CN}$ ) under an argon atmosphere at room temperature yields orange solid [8,8,8$\left.(\mathrm{H})\left(\mathrm{PPh}_{3}\right)_{2}-9-\left(3-\mathrm{Py}-\mathrm{CH}_{2} \mathrm{CN}\right)-n i d o-8,7-\mathrm{RhSB}_{9} \mathrm{H}_{9}\right]$ in $92 \%$ isolated yield (2, Scheme 1). 


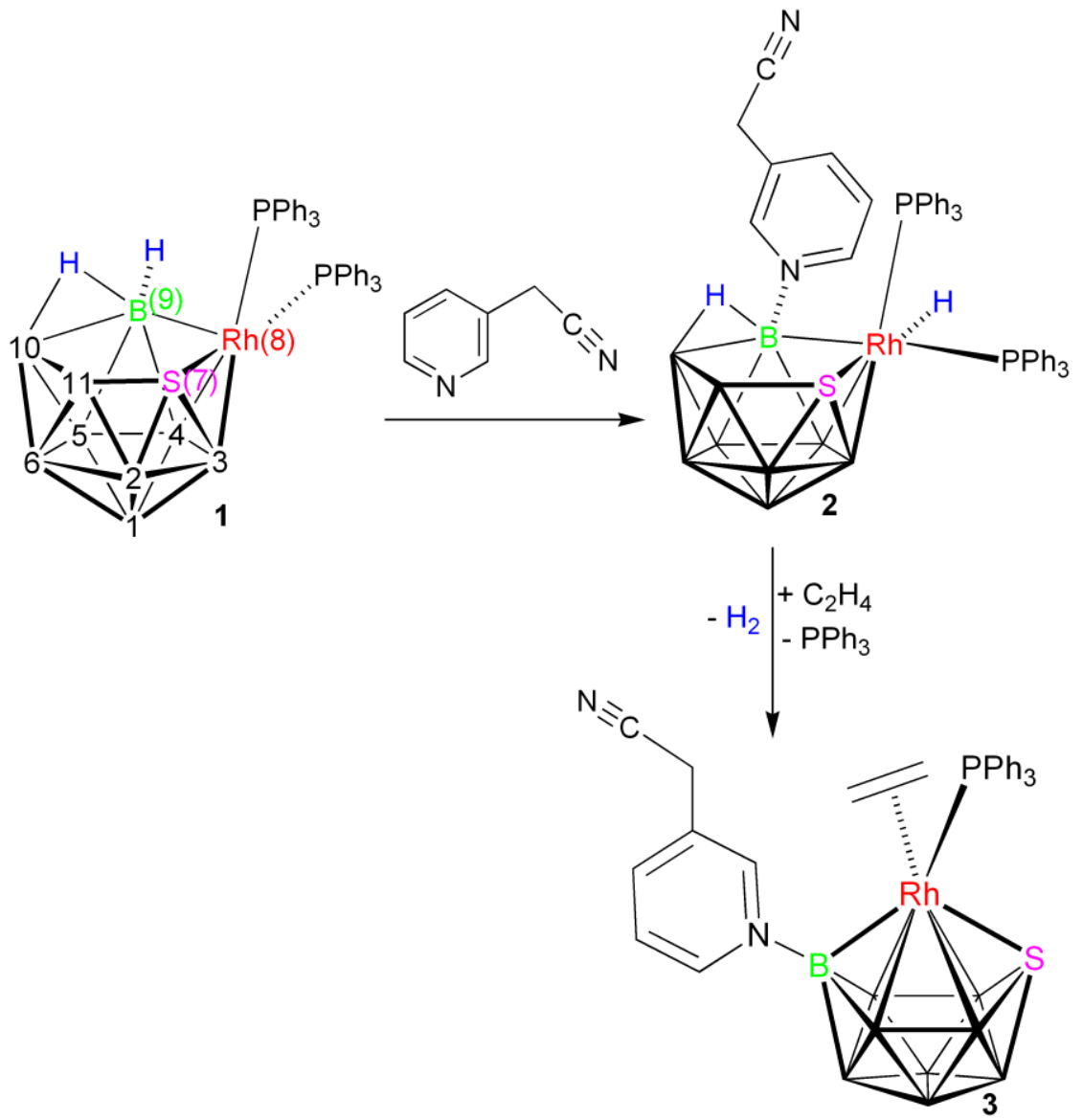

Scheme 2 Formation of [8,8,8-(H)( $\left.\mathrm{PPh}_{3}\right)_{2}-9-\left(3-\mathrm{Py}_{-} \mathrm{CH}_{2} \mathrm{CN}\right)-$ nido-8,7- $\left.\mathrm{RhSB}_{9} \mathrm{H}_{9}\right]$ (2) and its reaction with ethylene to give [1,1- $\left(\eta^{2}-\mathrm{C}_{2} \mathrm{H}_{4}\right)\left(\mathrm{PPh}_{3}\right)-3-\left(3-\mathrm{Py}_{-} \mathrm{CH}_{2} \mathrm{CN}\right)-$ closo-1,2$\left.\mathrm{RhSB}_{9} \mathrm{H}_{8}\right](3)$.

In this reaction, the terminal hydrogen atom at the $\mathrm{B}(9)$ vertex adjacent to the metal centre at position 8 , is formally substituted by the N-heterocyclic reagent, 3-Py- $\mathrm{CH}_{2} \mathrm{CN}$ (see Scheme 2 for the cluster numbering). The detailed mechanism of this reaction is unknown at this time, although two possible reaction pathways may be envisioned: $(a)$ the Lewis base directly attacks boron atom $\mathrm{B}(9)$, leading to the migration of the terminal hydrogen atom to the metal centre, $(b)$ the incoming ligand coordinates the metal centre and subsequently migrates to the $\mathrm{B}(9)$ vertex in a process that involves the concerted movement of the terminal hydrogen atom to the rhodium centre (Scheme 2). Alternatively, the $\mathrm{B}(9)-\mathrm{H}-\mathrm{B}(10)$ bridging hydrogen atom may be involved in both proposed concerted migrations instead of the terminal hydrogen atom, $\mathrm{B}(9)-\mathrm{H}$. Recently, we have demonstrated that the substitution reactions of $\mathbf{1}$ with monodentate phosphines follow an associative mechanism and, based on these results, it is therefore 
more probable that the formation of the hydridorhodathiaborane occurs via coordination of the incoming Lewis base to the metal centre.

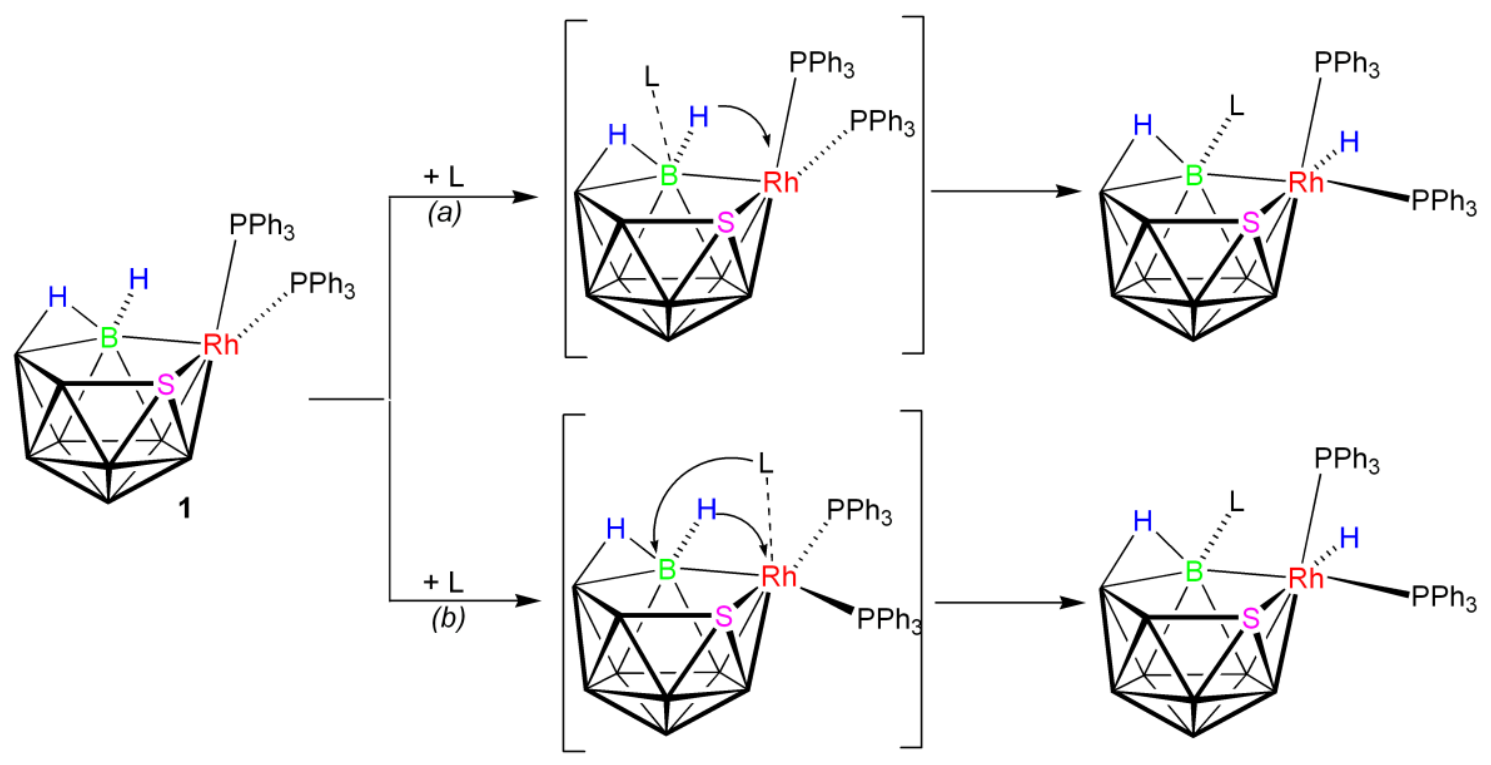

Scheme 3. Proposed pathways for the reaction of 1 with 3-Py- $\mathrm{CH}_{2} \mathrm{CN}(\mathrm{L})$ : (a) direct attack at the $\mathrm{B}(9)$ vertex, $(b)$ attack mediated by the metal centre.

The 3-pyridylacetonitrile-ligated hydridorhodathiaborane, 2, has been characterized by multielement NMR spectroscopy and mass spectrometry. This compound is sparingly soluble in dichloromethane, suggesting that the cluster may exhibit intermolecular interactions leading to an extended association in the solid state. Unfortunately, we have not yet been able to grow a crystal suitable for single-crystal X-ray diffraction analysis. The ${ }^{11} \mathrm{~B}-\left\{{ }^{1} \mathrm{H}\right\}$ NMR spectrum exhibits nine resonances ranging between $\delta_{\mathrm{B}}+12.1$ and $26.9 \mathrm{ppm}$, which is within the range found for the pyridine and picoline-ligated analogues, [8,8,8-(H)( $\left.\mathrm{PPh}_{3}\right)_{2}-9-(\mathrm{L})-$ nido-8,7- $\left.\mathrm{RhSB}_{9} \mathrm{H}_{9}\right]$, where $\mathrm{L}=\mathrm{Py}, 2-\mathrm{Me}-\mathrm{Py}, 3-\mathrm{Me}-$ Py and 4-Me-Py.[22] The highest frequency peak corresponds to the 3pyridylacetonitrile substituted boron atom as is found the pyridine and picoline analogues.

The ${ }^{1} \mathrm{H}-\left\{{ }^{11} \mathrm{~B}\right\}$ NMR spectrum of 2 shows a broad singlet and an apparent quartet in the high-field region, which may be assigned to the $\mathrm{B}(9)-\mathrm{B}(10)$ bridging hydrogen atom and to the $\mathrm{Rh}-\mathrm{H}$ hydride ligand, respectively. These spectroscopic data are diagnostic for this class of 11-vertex nido-hydridorhodathiaboranes. 
The low temperature ${ }^{31} \mathrm{P}-\left\{{ }^{1} \mathrm{H}\right\}$ spectrum of 2 exhibits two doublets-of-doublets with the resonance at highest frequency being much broader. This latter resonance increasingly broadens and shifts to lower frequency as the temperature is increased. The lowfrequency signal moves to a slightly higher frequency. This variable temperature NMR behaviour is similar to that found for the $\left[8,8,8-(\mathrm{H})\left(\mathrm{PPh}_{3}\right)_{2}-9-(\mathrm{L})-\right.$ nido-8,7- $\left.\mathrm{RhSB}_{9} \mathrm{H}_{9}\right]$ analogues (where L = Py, 2-Me-Py, 3-Me-Py and 4-Me-Py) [27].

It has been proposed that the temperature dependent broadening in the ${ }^{31} \mathrm{P}-\left\{{ }^{1} \mathrm{H}\right\}$ spectra of N-heterocyclic-ligated hydridorhodathiaboranes may arise mainly from the effects of "thermal decoupling" of the boron nuclei [28] together with the dissociation of the phosphine ligand trans to $\mathrm{B}(9)[22,23]$. Using this rationale, the broader peak at high frequency, in this new family of 11-vertex hydrido-ligated clusters, may be assigned to the phosphine ligand that is trans to the Lewis base-substituted boron vertex at the 9position.

Compound 2 reacts with ethylene to afford [1,1- $\left(\eta^{2}-\mathrm{C}_{2} \mathrm{H}_{4}\right)\left(\mathrm{PPh}_{3}\right)-3-\left(3-\mathrm{Py}_{-}-\mathrm{CH}_{2} \mathrm{CN}\right)-1,2-$ $\left.\mathrm{RhSB}_{9} \mathrm{H}_{8}\right]$ (3) in 74\% isolated yield, through 3-pyridylacetonitrile cage substitution and dihydrogen loss (vide infra), resulting in a cluster with a closo / isonido-electron count. This ethylene-ligated cluster has been characterized by multielement NMR spectroscopy and X-ray diffraction analysis. The ${ }^{11} \mathrm{~B}$ NMR spectrum shows seven signals a 1:1:2:1:1:1:2 relative intensity ratio in accord with an asymmetric cluster. The resonance at $\delta_{\mathrm{B}}+55.4 \mathrm{ppm}$ corresponds to the $\mathrm{B}(3)$ substituted 3-pyridylacetonitrile vertex. At room temperature in the ${ }^{1} \mathrm{H}$ NMR spectrum, the ethylene ligand shows two signals that split into four peaks at low temperature. This variable temperature behaviour demonstrates that the $\mathrm{Rh}-\left(\eta^{2}-\mathrm{C}_{2} \mathrm{H}_{4}\right)$ interaction is fluxional, undergoing a hindered rotation that renders the two $\mathrm{C}-\mathrm{H}$ pairs equivalent. The free energy barrier, calculated at the coalesce temperature, for this rotational process is $11.7 \mathrm{~kJ} / \mathrm{mol}$ (see supplementary material). This is also the activation energy $\Delta G^{\ddagger}$ found for the full rotation of the ethylene ligand about the coordination bond in the pyridine-ligated analogue, [1,1- $\left.\left(\eta^{2}-\mathrm{C}_{2} \mathrm{H}_{4}\right)\left(\mathrm{PPh}_{3}\right)-3-(\mathrm{Py})-1,2-\mathrm{RhSB}_{9} \mathrm{H}_{8}\right]$ (4) [22]. 


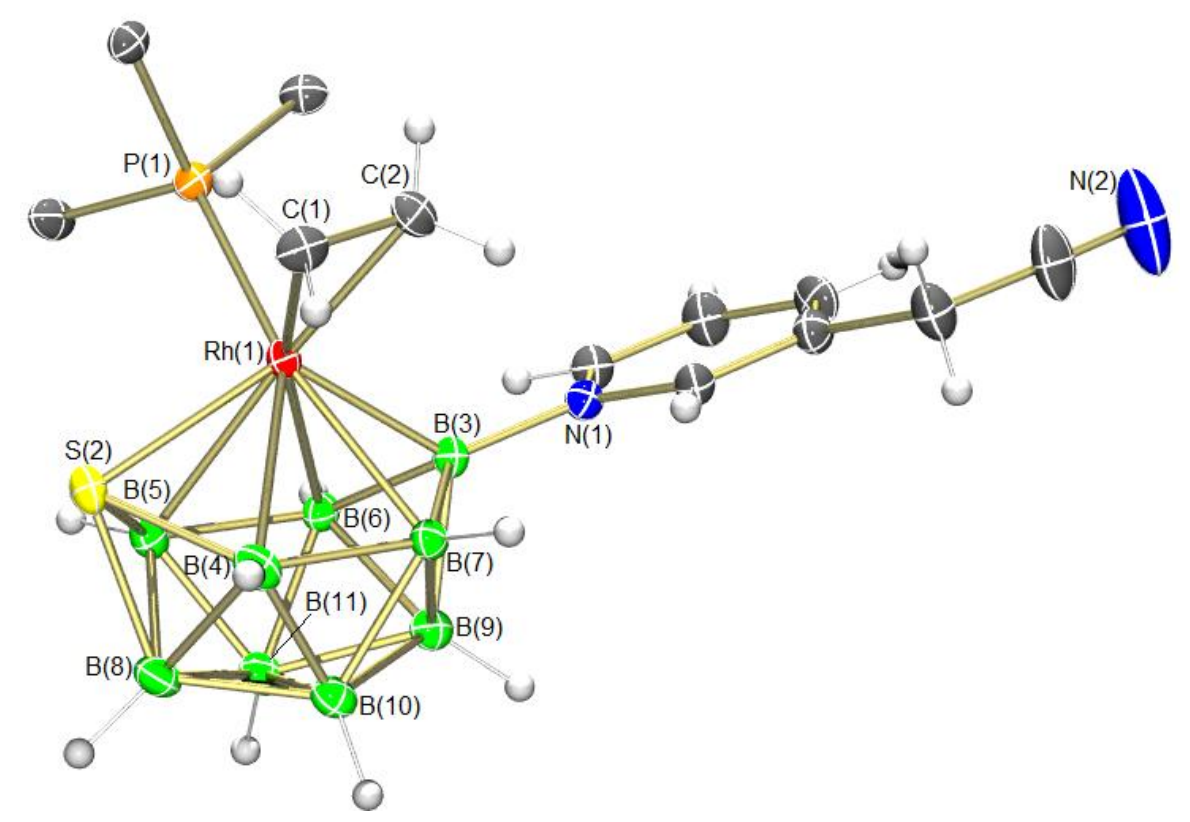

Figure 1 Crystallographically determined molecular structure of $\left[1,1-\left(\eta^{2}-\mathrm{C}_{2} \mathrm{H}_{4}\right)\left(\mathrm{PPh}_{3}\right)\right.$ 3-(3-Py- $\left.\mathrm{CH}_{2} \mathrm{CN}\right)$-closo-1,2- $\left.\mathrm{RhSB}_{9} \mathrm{H}_{8}\right]$ (compound 3).

Figure 1 depicts the molecular structure of $\mathbf{3}$ determined by X-ray diffraction and Table 1 lists selected distances and angles together with comparison values for the pyridineligated analogue, [1,1- $\left.\left(\eta^{2}-\mathrm{C}_{2} \mathrm{H}_{4}\right)\left(\mathrm{PPh}_{3}\right)-3-(\mathrm{Py})-1,2-\mathrm{RhSB}_{9} \mathrm{H}_{8}\right]$ (4) [22]. At first sight, the structure of the cluster is based on an octadecahedron. It should be noted that both, the 3-pyridyl-acetonitrile and the pyridine derivatives, feature long $\mathrm{Rh}(1)-\mathrm{B}(5)$ distances close to $2.5 \AA$, which is the upper limit normally considered as bonding. This relatively long $\mathrm{Rh}(1)-\mathrm{B}(5)$ linkage is trans to the $\eta^{2}$-ethylene ligand in both rhodathiaboranes, 3 and 4. This type of elongation has been found in others 11-vertex metallaheteroboranes that exhibit a pseudo-square open face [29], which represent intermediates along the structural continuum from closo to nido [30-33]. 


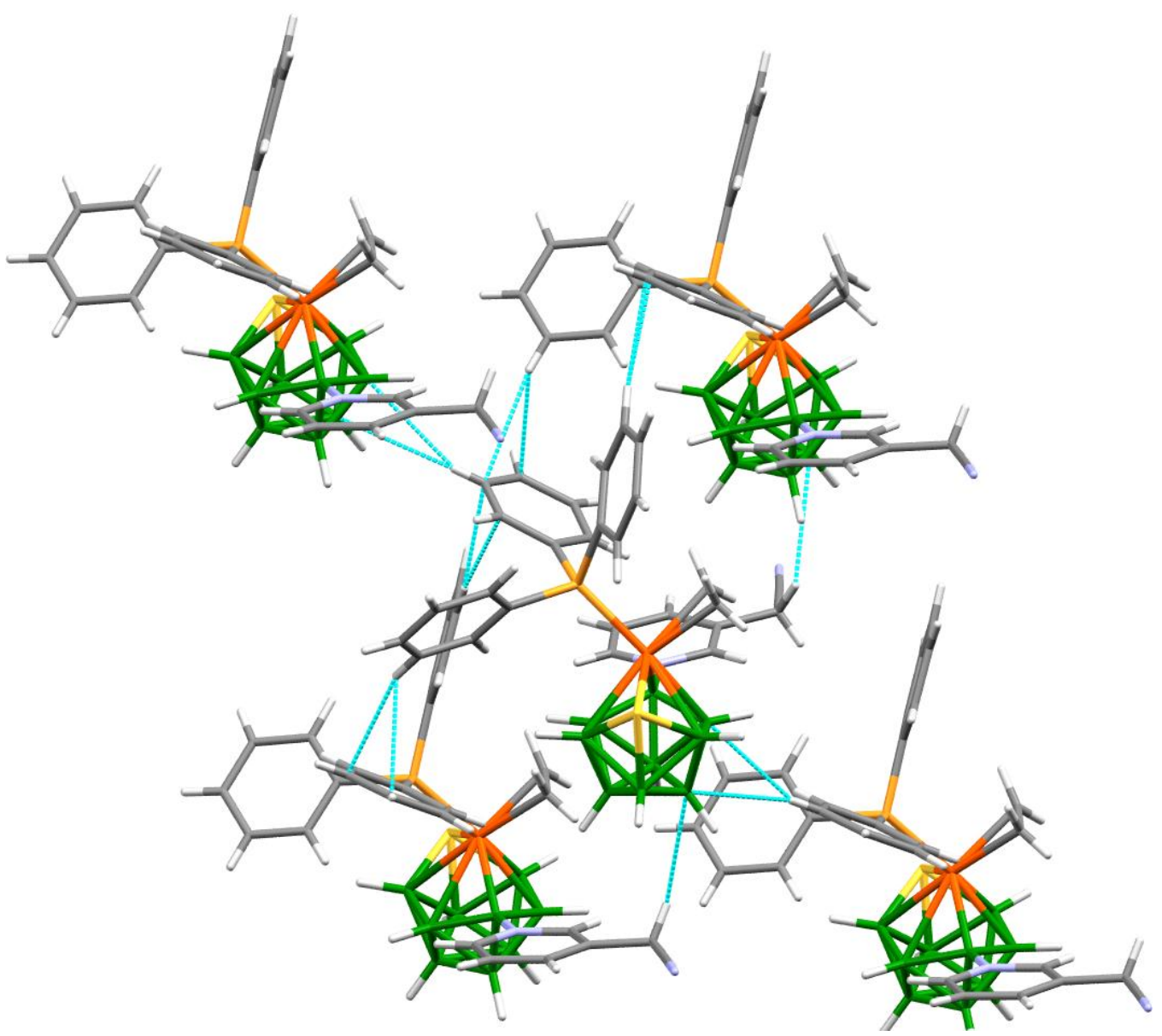

Figure 2 Section of the crystal structure of $\left[1,1-\left(\eta^{2}-\mathrm{C}_{2} \mathrm{H}_{4}\right)\left(\mathrm{PPh}_{3}\right)-3-\left(3-\mathrm{Py}_{-}-\mathrm{CH}_{2} \mathrm{CN}\right)\right.$ closo-1,2- $\mathrm{RhSB}_{9} \mathrm{H}_{8}$ ] (compound 3), showing the short contacts between the clusters. There are edge-to-face $\pi$-interactions between the phenyl rings ranging from 2.70-2.85 $\AA$, and $\mathrm{B}{ }^{\cdots} \mathrm{H}-\mathrm{C}$ distances at 2.97 and $3.13 \AA$ between the $\mathrm{C}-\mathrm{H}$ units of one phenyl rings and the $\mathrm{B}(7)$ and $\mathrm{B}(10)$ vertices, and between a $\mathrm{C}-\mathrm{H}$ unit of the acetonitrile group and the $\mathrm{B}(10)$ vertex at $3.12 \AA$.

In the crystal lattice, the clusters show intermolecular edge-to-face $\pi$-interactions. The observed $\mathrm{C}-\mathrm{H}^{\cdots} \mathrm{C}$ contacts are in the range $2.70-2.85 \AA$, being shorter than the Van der Waals radii. Each cluster shows three of these interactions with two adjacent neighbors (Figure 2). It is noteworthy that these attractive $\pi$-forces lead to the approach of the $B(7)$ and $\mathrm{B}(10)$ vertices and $\mathrm{C}-\mathrm{H}$ unit of phenyl rings and the $-\mathrm{CH}_{2} \mathrm{CN}$ dangling groups between adjacent clusters. The result is the formation of chains that grow along the crystallographic $c$-axis. These chains pack on the $a c$-plane to form a layer, which selfassemble, via the commented $\pi$-interactions, with an adjacent parallel layer, forming an 
AB-type of a double layer. The repetition of this close-packed double layer in the unit cell forms the solid structure of compound $\mathbf{3}$ (Figure 3).

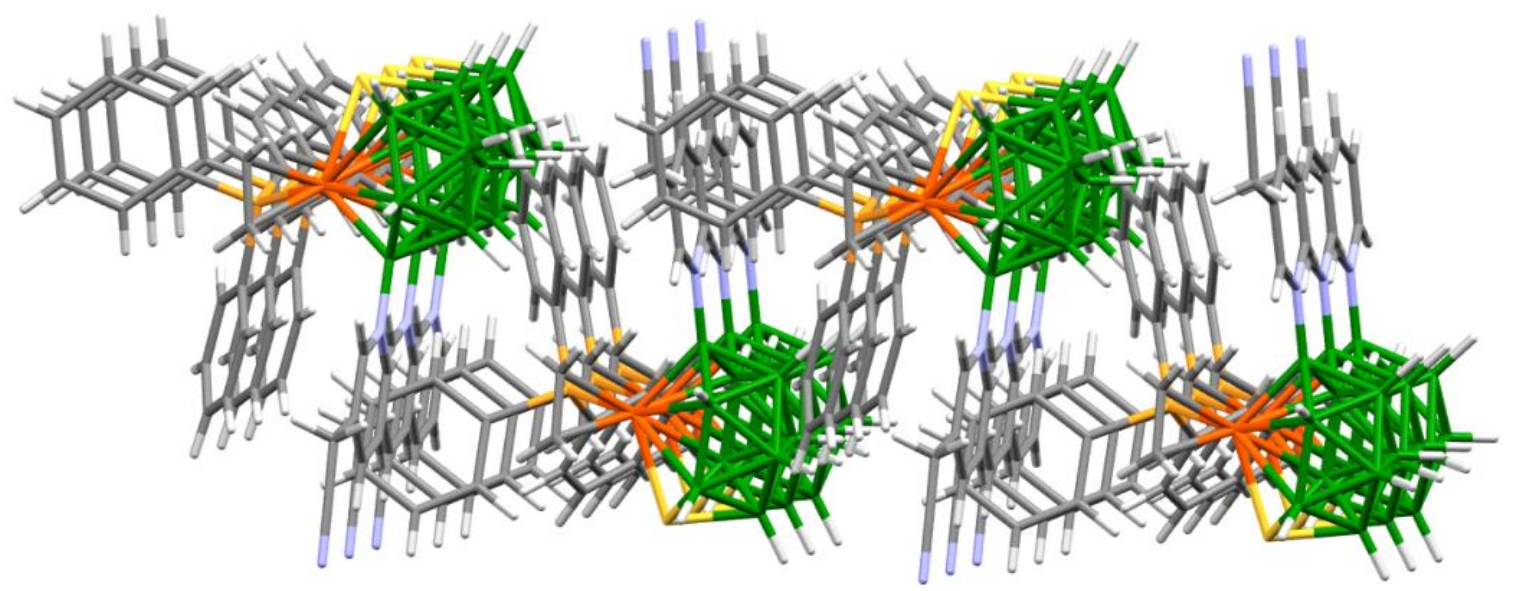

Figure 3 Packing of the crystal structure of $\left[1,1-\left(\eta^{2}-\mathrm{C}_{2} \mathrm{H}_{4}\right)\left(\mathrm{PPh}_{3}\right)-3-\left(3-\mathrm{Py}_{-}-\mathrm{CH}_{2} \mathrm{CN}\right)-\right.$ closo-1,2- $\left.\mathrm{RhSB}_{9} \mathrm{H}_{8}\right]$ (compound 3). View along the $c$-axis: the layers grow on the $a c$ plane.

It is interesting to note that the low resolution mass spectra of compounds $\mathbf{2}$ and $\mathbf{3}$ give an ion centred at $\mathrm{m} / \mathrm{z}, 979$ with an isotopic pattern that matches well a molecular ion with the formula, $\left[\left\{\left(\mathrm{PPh}_{3}\right)\left(\mathrm{RhSB}_{9} \mathrm{H}_{8}\right)\right\}\left(3-\mathrm{Py}_{-}-\mathrm{CH}_{2} \mathrm{CN}\right)\left\{3-\mathrm{Py}_{-}-\mathrm{CH}_{2} \mathrm{CN}\left(\mathrm{RhSB}_{9} \mathrm{H}_{8}\right)\right]^{+}\right.$(see Figures S1 and S2). A reasonable interpretation is that this ion contains a $\left\{\left(\mathrm{PPh}_{3}\right)\left(\mathrm{RhSB}_{9} \mathrm{H}_{8}\right)\right\}$ fragment and a $\left\{\left(3-\mathrm{Py}-\mathrm{CH}_{2} \mathrm{CN}\right)\left(\mathrm{RhSB}_{9} \mathrm{H}_{8}\right)\right\}$ unit bridged by a 3pyridyl ligand. In addition, the spectra show the fragmented ion $\left[\left(\mathrm{PPh}_{3}\right) \mathrm{RhSB}_{9} \mathrm{H}_{8}(3-\mathrm{Py}-\right.$ $\mathrm{CH}_{2} \mathrm{CN}$ ) $]^{+}$at $m / z 621$ (Figure 4). These results suggest that the dangling nitrile group in compounds $\mathbf{2}$ and $\mathbf{3}$ can coordinate other metal centers leading to the formation of dimeric species:

$2\left[(\mathrm{H})\left(\mathrm{PPh}_{3}\right)_{2} \mathrm{RhSB}_{9} \mathrm{H}_{9}\left(3-\mathrm{Py}_{-} \mathrm{CH}_{2} \mathrm{CN}\right)\right]^{\bullet+} \rightarrow\left[\left\{\left(\mathrm{PPh}_{3}\right) \mathrm{RhSB}_{9} \mathrm{H}_{8}\right\}\left(3-\mathrm{Py}_{-} \mathrm{CH}_{2} \mathrm{CN}\right)\{(3-\mathrm{Py}-\right.$ $\left.\left.\left.\mathrm{CH}_{2} \mathrm{CN}\right) \mathrm{RhSB}_{9} \mathrm{H}_{8}\right\}\right]^{\bullet+}+4 \mathrm{H}+3 \mathrm{PPh}_{3}$

$2\left[\left(\mathrm{C}_{2} \mathrm{H}_{4}\right)\left(\mathrm{PPh}_{3}\right) \mathrm{RhSB}_{9} \mathrm{H}_{8}\left(3-\mathrm{Py}-\mathrm{CH}_{2} \mathrm{CN}\right)\right]^{\bullet+} \rightarrow\left[\left\{\left(\mathrm{PPh}_{3}\right) \mathrm{RhSB}_{9} \mathrm{H}_{8}\right\}\left(3-\mathrm{Py}_{-}-\mathrm{CH}_{2} \mathrm{CN}\right)\{(3-\mathrm{Py}-\right.$ $\left.\left.\left.\mathrm{CH}_{2} \mathrm{CN}\right) \mathrm{RhSB}_{9} \mathrm{H}_{8}\right\}\right]^{\bullet+}+\mathrm{PPh}_{3}+2 \mathrm{C}_{2} \mathrm{H}_{4}$ 
The observed fragmentation processes involve the loss of dihydrogen and one $\mathrm{PPh}_{3}$ ligand from the hydridorhodathiaborane 2 , and the ethylene ligand from $\mathbf{3}$ :

$\left[(\mathrm{H})\left(\mathrm{PPh}_{3}\right)_{2} \mathrm{RhSB}_{9} \mathrm{H}_{9}\left(3-\mathrm{Py}_{-} \mathrm{CH}_{2} \mathrm{CN}\right]^{\bullet+} \rightarrow\left[\left(\mathrm{PPh}_{3}\right) \mathrm{RhSB}_{9} \mathrm{H}_{8}\left(3-\mathrm{Py}_{-} \mathrm{CH}_{2} \mathrm{CN}\right]^{\bullet+}+2 \mathrm{H}+\mathrm{PPh}_{3}\right.\right.$ $\left[\left(\mathrm{C}_{2} \mathrm{H}_{4}\right)\left(\mathrm{PPh}_{3}\right) \mathrm{RhSB}_{9} \mathrm{H}_{8}\left(3-\mathrm{Py}-\mathrm{CH}_{2} \mathrm{CN}\right]^{\bullet+} \rightarrow\left[\left(\mathrm{PPh}_{3}\right) \mathrm{RhSB}_{9} \mathrm{H}_{8}\left(3-\mathrm{Py}_{-}-\mathrm{CH}_{2} \mathrm{CN}\right]^{\bullet+}+\mathrm{C}_{2} \mathrm{H}_{4}\right.\right.$

It should be noted that identical results were obtained using the matrices DCTB, terthiophene and dithranol, suggesting that the formation of the dimeric ion is a fundamental property of these 3-pyridyl-ligated clusters.

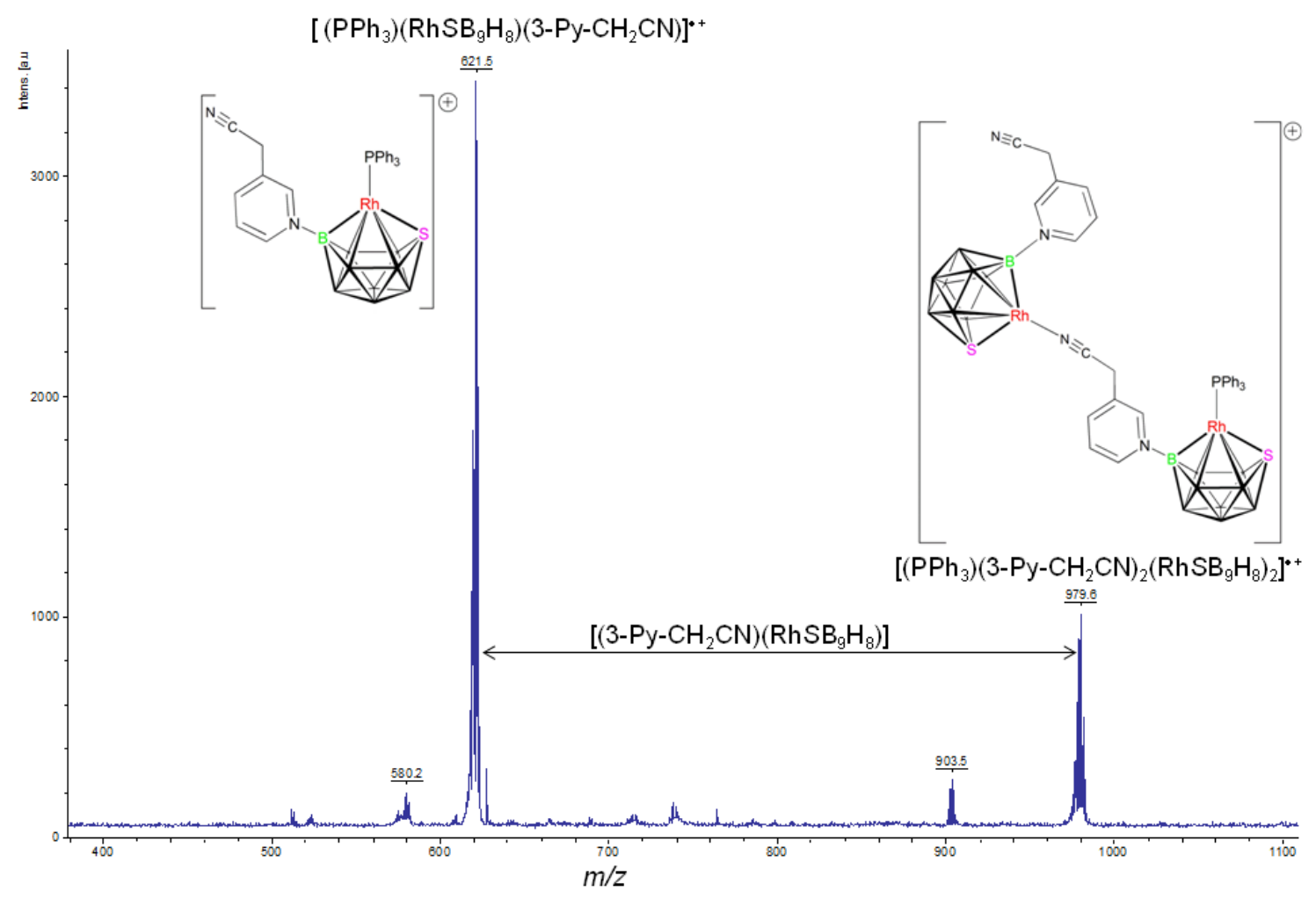

Figure 4 Positive ion LSMS spectrum of [1,1- $\left(\eta^{2}-\mathrm{C}_{2} \mathrm{H}_{4}\right)\left(\mathrm{PPh}_{3}\right)-3-\left(3-\mathrm{Py}-\mathrm{CH}_{2} \mathrm{CN}\right)$-closo1,2- $\left.\mathrm{RhSB}_{9} \mathrm{H}_{8}\right]$ (compound 3).

\section{Conclusion}

Reaction of the 11-vertex rhodathiaborane 1 with 3-pyridylacetonitrile is a convenient method for the modification of the boron-bound exo-polyhedral ligands in 11-vertex rhodathiaboranes. The resulting labile hydridorhodathiaborane 2 reacts with ethylene to 
give an ethylene-ligated cluster, which has been characterized by X-ray diffraction analysis. This is only the second crystallographically-determined ethylene-ligated polyhedral boron-based cluster reported in the literature.

The dangling nitrile group in compounds $\mathbf{2}$ and $\mathbf{3}$ is open for coordination to other metal centres: thus, both clusters are appropriate reagents for the potential synthesis of bimetallic systems. In addition, the reaction of $\mathbf{3}$ with dihydrogen may afford unsaturated species, formed by release of ethane, which could lead to intercluster coordination via the nitrile groups.

The incorporation of 3-pyridylacetonitrile on the 11-vertex nido- and closo-clusters is straight-forward method for the modification of the exo-polyhedral surface of the clusters, thereby opening new possibilities for coordination of different metals and leading to the development of their reaction chemistry. 
Table 1. Selected interatomic distances $(\AA)$ and angles $\left(^{\circ}\right)$ with Estimated Standard Uncertainties (s.u.) in parentheses for [1,1- $\left(\eta^{2}-\mathrm{C}_{2} \mathrm{H}_{4}\right)\left(\mathrm{PPh}_{3}\right)-3-(3-$ $\left.\mathrm{NCCH}_{2} \mathrm{Py}\right)$-closo-1,3-RhSB $\left.{ }_{9} \mathrm{H}_{8}\right] 3$ and [1,1- $\left(\eta^{2}-\mathrm{C}_{2} \mathrm{H}_{4}\right)\left(\mathrm{PPh}_{3}\right)-3-(\mathrm{Py})$-closo1,3-RhSB $\left.{ }_{9} \mathrm{H}_{8}\right] 4$.

\begin{tabular}{ccc}
\hline & 3 & $4^{[22]}$ \\
\hline $\mathrm{Rh}(1)-\mathrm{S}(2)$ & $2.3615(7)$ & $2.3721(9)$ \\
$\mathrm{Rh}(1)-\mathrm{P}(1)$ & $2.3000(7)$ & $2.2981(9)$ \\
$\mathrm{Rh}(1)-\mathrm{C}(1)$ & $2.164(3)$ & $2.165(3)$ \\
$\mathrm{Rh}(1)-\mathrm{C}(2)$ & $2.172(3)$ & $2.171(4)$ \\
$\mathrm{Rh}(1)-\mathrm{B}(3)$ & $2.087(3)$ & $2.079(4)$ \\
$\mathrm{Rh}(1)-\mathrm{B}(4)$ & $2.445(3)$ & $2.427(4)$ \\
$\mathrm{Rh}(1)-\mathrm{B}(5)$ & $2.490(3)$ & $2.503(4)$ \\
$\mathrm{Rh}(1)-\mathrm{B}(6)$ & $2.411(3)$ & $2.365(4)$ \\
$\mathrm{Rh}(1)-\mathrm{B}(7)$ & $2.330(3)$ & $2.376(4)$ \\
$\mathrm{S}(2)-\mathrm{B}(4)$ & $1.938(3)$ & $1.948(4)$ \\
$\mathrm{S}(2)-\mathrm{B}(5)$ & $1.935(3)$ & $1.929(4)$ \\
$\mathrm{S}(2)-\mathrm{B}(8)$ & $1.990(3)$ & $1.985(4)$ \\
$\mathrm{C}(1)-\mathrm{C}(2)$ & $1.383(4)$ & $1.383(5)$ \\
$\mathrm{N}(1)-\mathrm{B}(3)$ & $1.544(3)$ & $1.539(5)$ \\
$\mathrm{P}(1)-\mathrm{Rh}(1)-\mathrm{S}(2)$ & $103.81(2)$ & $112.86(3)$ \\
$\mathrm{P}(1)-\mathrm{Rh}(1)-\mathrm{B}(3)$ & $116.85(8)$ & $109.13(11)$ \\
$\mathrm{S}(2)-\mathrm{Rh}(1)-\mathrm{B}(3)$ & $119.34(8)$ & $119.58(11)$ \\
$\mathrm{Rh}(1)-\mathrm{B}(3)-\mathrm{N}(1)$ & $130.72(19)$ & $127.7(2)$ \\
$\mathrm{C}(1)-\mathrm{Rh}(1)-\mathrm{P}(1)$ & $95.84(8)$ & $89.32(11)$ \\
$\mathrm{C}(2)-\mathrm{Rh}(1)-\mathrm{P}(1)$ & $89.08(8)$ & \\
\hline & & \\
\hline
\end{tabular}


Table 2 Crystallographic Data and Structure Refinement Information for [1,1- $\left(\eta^{2}-\mathrm{C}_{2} \mathrm{H}_{4}\right)\left(\mathrm{PPh}_{3}\right)-3-\left(3-\mathrm{Py}-\mathrm{CH}_{2} \mathrm{CN}\right)$-closo-1,2$\mathrm{RhSB}_{9} \mathrm{H}_{8}$ ] (compound 3).

\begin{tabular}{ll}
\hline Chemical formula & $\mathrm{C}_{27} \mathrm{H}_{33} \mathrm{~B}_{9} \mathrm{~N}_{2} \mathrm{PRhS}$ \\
Formula Mass & 648.82 \\
Crystal system & Monoclinic \\
$a / \AA$ & $11.1218(8)$ \\
$b / \AA$ & $21.6719(15)$ \\
$c / \AA$ & $13.8727(10)$ \\
$\alpha /^{\circ}$ & 90.00 \\
$\beta /^{\circ}$ & $113.3086(10)$ \\
$\gamma /{ }^{\circ}$ & 90.00 \\
Unit cell volume/ ${ }^{3}$ & $3070.9(4)$ \\
Temperature/K & $100(2)$ \\
Space group & $P 21 / n$ \\
No. of formula units per unit cell, $Z$ & 4 \\
Radiation type & MoK $\alpha$ \\
Absorption coefficient, $\mu / \mathrm{mm}^{-1}$ & 0.698 \\
No. of reflections measured & 33287 \\
No. of independent reflections & 8019 \\
$R_{\text {int }}$ & 0.0612 \\
Final $R_{I}$ values $(I>2 \sigma(I))$ & 0.0371 \\
Final $w R\left(F^{2}\right)$ values $(I>2 \sigma(I))$ & 0.0711 \\
Final $R_{I}$ values (all data) & 0.0687 \\
Final $w R\left(F^{2}\right)$ values (all data) & 0.0805 \\
Goodness of fit on $F^{2}$ & 1.010 \\
\hline
\end{tabular}




\section{Experimental}

\subsection{General Procedures}

Reactions were carried out under an argon atmosphere using standard Schlenk-line techniques. Solvents were obtained dried from a Solvent Purification System of Innovative Technology Inc. The 11-vertex rhodathiaborane 1 was prepared according to the literature methods [21]. NMR spectra were recorded on Bruker Avance 300-MHz and AV 400-MHz spectrometers, using ${ }^{31} \mathrm{P}-\left\{{ }^{1} \mathrm{H}\right\},{ }^{11} \mathrm{~B},{ }^{11} \mathrm{~B}-\left\{{ }^{1} \mathrm{H}\right\},{ }^{1} \mathrm{H},{ }^{1} \mathrm{H}-\left\{{ }^{11} \mathrm{~B}\right\}$ and ${ }^{1} \mathrm{H}-$ $\left\{{ }^{11} \mathrm{~B}\right.$ (selective $\left.)\right\}$ techniques. Residual solvent protons were used as reference $(\delta$, ppm, $\left.\mathrm{CDCl}_{3}, 7.26 ; \mathrm{CD}_{2} \mathrm{Cl}_{2}, 5.33 ; \mathrm{CD}_{3} \mathrm{CN}, 1.96\right) .{ }^{11} \mathrm{~B}$ chemical shifts are quoted relative to $\left.\left[\mathrm{BF}_{3}(\mathrm{OEt})_{2}\right)\right]$ and ${ }^{31} \mathrm{P}$ chemical shifts are quoted relative to $85 \%$ aqueous $\mathrm{H}_{3} \mathrm{PO}_{4}$. Mass spectrometric data were recorded on a MICROFLEX instrument operating in the positive mode, using matrix-assisted laser desorption ionization (MALDI). A nitrogen laser of $337 \mathrm{~nm}$ (photon energy of $3.68 \mathrm{eV}$ ) was used for the ionization processes, and the molecules under study were protected with three matrices: trans-2-[3-(4-tertButylphenyl)-2-methyl-2-propenylidene]malononitrile (DCTB), dithramol and terthiophene.

\subsection{X-ray crystallography}

Crystals of compound $\mathbf{3}$ suitable for X-ray diffraction analysis were grown by slow diffusion of hexane into a concentrated solution of the rhodathiaborane in dichloromethane. X-ray diffraction data were collected at low temperature $(100(2) \mathrm{K})$ on an automatic Bruker Kappa APEX DUO CCD area detector diffractometer equipped with graphite-monochromatic Mo- $\mathrm{K}_{\alpha}$ radiation $(\lambda=0.71073 \AA)$ using narrow frames $\left(0.3^{\circ}\right.$ in $\left.\omega\right)$. In all cases, single crystals were mounted on a fiber and were covered with a protective perfluoropolyether. Intensities were integrated including Lorentz and polarization effect with SAINT-Plus program [34] and corrected for absorption using multi-scan methods applied with SADABS program [35]. The structures were solved using the SHELXS-97 program [36]. Refinements were carried out by full-matrix leastsquares on $F^{2}$ with SHELXL-97 [37], including isotropic and subsequent anisotropic displacement parameters for all non-hydrogen atoms. Experimental diffraction parameters and crystal data are gathered in Table 3. 


\subsection{Synthesis and NMR data}

4.3.1. [8,8,8-(H)( $\left.\mathrm{PPh}_{3}\right)-9-\left(3-\mathrm{Py}-\mathrm{CH}_{2}-\mathrm{CN}\right)-$ nido-8,7-RhSB$\left.{ }_{9} \mathrm{H}_{9}\right]$ (2). In a Schlenk tube, $116 \mathrm{mg}(0.151 \mathrm{mmol})$ of 1 was dissolved in $10 \mathrm{~mL}$ of $\mathrm{CH}_{2} \mathrm{Cl}_{2}$, resulting in a bright-red solution. $160 \mu \mathrm{l}(179 \mathrm{mg}, 1.51 \mathrm{mmol})$ of 3-pyridylacetonitrile $\left(3-\mathrm{Py}_{-} \mathrm{CH}_{2} \mathrm{CN}\right)$ was syringed into the solution, and the reaction mixture was stirred at room temperature for 7 hours. After this time the solvent was evaporated to dryness and the solid residue washed three times with hexane. The final product was characterized as compound 2. Yield: $100.8 \mathrm{mg}, 0.139 \mathrm{mmol}, 92 \%$. IR (ATR): v 2535 vs (BH), 2511 vs (BH), 2460 vs (BH), $2255 \mathrm{w}(\mathrm{CN}), 2060 \mathrm{~m}(\mathrm{RhH}) .{ }^{11} \mathrm{~B}-\left\{{ }^{1} \mathrm{H}\right\} \mathrm{NMR}\left(128 \mathrm{MHz} ; \mathrm{CD}_{2} \mathrm{Cl}_{2} ; 298 \mathrm{~K}\right): \delta$ $+12.1,+7.8,+3.5,+0.3,-3.8,-9.9,-18.5,-25.6,-29.6 .{ }^{1} \mathrm{H} \mathrm{NMR}\left(500 \mathrm{MHz} ; \mathrm{CD}_{2} \mathrm{Cl}_{2}\right.$; 298K): $\delta+7.91\left(1 \mathrm{H}\right.$, br, 3- $\left.\mathrm{PyCH}_{2} \mathrm{CN}\right),+7.82\left(1 \mathrm{H}\right.$, br, 3- $\left.-\mathrm{PyCH}_{2} \mathrm{CN}\right),+7.35-+7.05$ (aromatics, $\left.\mathrm{PPh}_{3}\right),+4.04(\mathrm{v}$ br, $\mathrm{BH}),+3.67\left(\mathrm{ABq}, 1 \mathrm{H}, \Delta v_{\mathrm{AB}}=30.8 \mathrm{~Hz}, J_{\mathrm{AB}}=19.2 \mathrm{~Hz}\right.$, $\left.\mathrm{CH}_{2} \mathrm{CN}\right),+3.55\left(\mathrm{ABq}, \mathrm{CH}_{2} \mathrm{CN}\right),+2.85$ (v br, BH), +1.84 (v br, BH), -1.37 (br s, BHB), -12.51 (apparent q, $J=18.9 \mathrm{~Hz}, \mathrm{RhH}$ ); due to the insolubility of the compound, the terminal B-H peaks could not be observed. ${ }^{31} \mathrm{P}-\left\{{ }^{1} \mathrm{H}\right\}$ NMR $\left(121 \mathrm{MHz} ; \mathrm{CD}_{2} \mathrm{Cl}_{2} ; 298 \mathrm{~K}\right)$ : $\delta+33.7\left(\mathrm{v}\right.$ br) $,+32.3\left(\right.$ br d, $\left.J_{\mathrm{RhP}}=97 \mathrm{~Hz}\right), 37.4\left(\mathrm{~d}, J_{\mathrm{RhP}}=144 \mathrm{~Hz}\right),+28.3\left(\mathrm{~s}, \mathrm{O}=\mathrm{PPh}_{3}\right)$. ${ }^{31} \mathrm{P}-\left\{{ }^{1} \mathrm{H}\right\}$ NMR $\left(121 \mathrm{MHz} ; \mathrm{CD}_{2} \mathrm{Cl}_{2} ; 213 \mathrm{~K}\right): \delta+36.3\left(\mathrm{dd}, J_{\mathrm{RhP}}=104.1 \mathrm{~Hz}\right),+30.4(\mathrm{dd}$, $\left.J_{\mathrm{RhP}}=127.1 \mathrm{~Hz},{ }^{2} J_{\mathrm{PP}}=19 \mathrm{~Hz}\right) . \mathrm{LRMS}\left(\mathrm{MALDI}^{+} / \mathrm{DCTB}\right): m / z \quad\left[2 \mathrm{M}-3\left(\mathrm{PPh}_{3}\right)-4 \mathrm{H}\right]^{+}$ obsvd 979, calcd for $\mathrm{P}_{1} \mathrm{C}_{32} \mathrm{H}_{43} \mathrm{Rh}_{2} \mathrm{~S}_{2} \mathrm{~B}_{18} \mathrm{~N}_{4}$ : 979; [M - $\left.\mathrm{PPh}_{3}-2 \mathrm{H}\right]^{+}$obsvd 621, calcd for $\mathrm{P}_{1} \mathrm{C}_{25} \mathrm{H}_{29} \mathrm{Rh}_{1} \mathrm{~S}_{1} \mathrm{~B}_{9} \mathrm{~N}_{2}: 621$. The obsvd isotope envelope matches that calculated from the known isotopic abundances of the constituent elements.

4.3.2. [1,1-( $\left.\mathrm{PPh}_{3}\right)\left(\boldsymbol{\eta}^{2}-\mathrm{C}_{2} \mathbf{H}_{4}\right)$-3-(3-Py-CH $\left.\mathbf{C H}_{2} \mathrm{CN}\right)$-closo-1,2-RhSB $\left.{ }_{9} \mathrm{H}_{8}\right]$ (3): $50 \mathrm{mg}(0.056$ $\mathrm{mmol})$ of $\left[8,8,8-(\mathrm{H})\left(\mathrm{PPh}_{3}\right)_{2}-9-\left(3-\mathrm{Py}_{-} \mathrm{CH}_{2}-\mathrm{CN}\right)-\right.$ nido-8,7- $\left.\mathrm{RhSB}_{9} \mathrm{H}_{9}\right]$ (2) was dissolved in $10 \mathrm{ml}$ of $\mathrm{CH}_{2} \mathrm{Cl}_{2}$ in a Schlenk tube. After three freeze-thaw cycles, a balloon containing ethylene was attached to the Schlenk tube, and the rhodathiaborane solution exposed to the gas. The system was stirred at room temperature for $24 \mathrm{~h}$ and then concentrated by solvent evaporation under vacuum, after which hexane was added to produce an orangered precipitate, which was then washed several times with hexane. The solid was crystallized from $\mathrm{CH}_{2} \mathrm{Cl}_{2}$ /hexane to isolate the respective ethylene-ligated cluster, [1,1$\left(\eta^{2}-\mathrm{C}_{2} \mathrm{H}_{4}\right)\left(\mathrm{PPh}_{3}\right)-3-\left(3-\mathrm{Py}-\mathrm{CH}_{2} \mathrm{CN}\right)$-closo-1,2-RhSB $\left.{ }_{9} \mathrm{H}_{8}\right]$. Yield: $27 \mathrm{mg}, 0.042 \mathrm{mmol}$, 74\%. IR (ATR): v 2529 vs (BH), 2509 vs (BH). ${ }^{11} \mathrm{~B}-\left\{{ }^{1} \mathrm{H}\right\}$ NMR (96 MHz, $\mathrm{CDCl}_{3}, 298$ $\mathrm{K}): \delta+55.4(\mathrm{~s}, \mathrm{~B}-\mathrm{N}),+26.2\left(\mathrm{~s}, \mathrm{BH},{ }^{1} J\left({ }^{11} \mathrm{~B}-{ }^{1} \mathrm{H}\right)=122 \mathrm{~Hz}\right),+1.1(\mathrm{~s}, 2 \mathrm{~B}-\mathrm{H}),-14.2(\mathrm{~s}, \mathrm{~B}-$ $\mathrm{H}),-21.9\left(\mathrm{~s}, \mathrm{~B}-\mathrm{H},{ }^{1} \mathrm{~J}\left({ }^{11} \mathrm{~B}-{ }^{1} \mathrm{H}\right)=128 \mathrm{~Hz}\right),-24.5\left(\mathrm{~s}, \mathrm{~B}-\mathrm{H},{ }^{1} \mathrm{~J}\left({ }^{11} \mathrm{~B}-{ }^{1} \mathrm{H}\right)=126 \mathrm{~Hz}\right),-29.8(\mathrm{~s}$, 
2B-H). ${ }^{1} \mathrm{H}-\left\{{ }^{11} \mathrm{~B}\right\} \mathrm{NMR}\left(300 \mathrm{MHz}, \mathrm{CDCl}_{3}, 298 \mathrm{~K}\right): \delta+9.30\left(1 \mathrm{H}\right.$, br, 3- $\left.\mathrm{PyCH}_{2} \mathrm{CN}\right)$, +9.19 $\left(1 \mathrm{H}\right.$, br, 3- $\left.\mathrm{PyCH}_{2} \mathrm{CN}\right),+8.35\left(1 \mathrm{H}\right.$, br, 3- $\left.\mathrm{PyCH}_{2} \mathrm{CN}\right),+7.84\left(1 \mathrm{H}\right.$, br, 3- $\left.\mathrm{PyCH}_{2} \mathrm{CN}\right)$, $+4.22(\mathrm{~s}, \mathrm{~B}-\mathrm{H}),+3.94\left(\mathrm{ABq}, 1 \mathrm{H}, \Delta v_{\mathrm{AB}}=27.5 \mathrm{~Hz}, J_{\mathrm{AB}}=18.5 \mathrm{~Hz}, \mathrm{CH}_{2} \mathrm{CN}\right),+3.81$ $\left(\mathrm{ABq}, \mathrm{CH}_{2} \mathrm{CN}\right),+2.27(\mathrm{~s}, \mathrm{~B}-\mathrm{H}),+2.28\left(\mathrm{C}_{2} \mathrm{H}_{4}\right),+2.09\left(\mathrm{C}_{2} \mathrm{H}_{4}\right),+1.96(\mathrm{~s}, \mathrm{~B}-\mathrm{H}),+1.60(\mathrm{~s}$, $\mathrm{B}-\mathrm{H}),+0.43$ (s, B-H), 0.22 (s, B-H), -0.19 (s, B-H), -0.23 (s, B-H). ${ }^{31} \mathrm{P}-\left\{{ }^{1} \mathrm{H}\right\}$ NMR $\left(121 \mathrm{MHz}, \mathrm{CDCl}_{3}, 298 \mathrm{~K}\right): \delta+39.0\left(\mathrm{~d}, \mathrm{PPh}_{3}, J_{\mathrm{RhP}}=141 \mathrm{~Hz}\right)$. LRMS $\left(\mathrm{MALDI}^{+} / \mathrm{DCTB}\right)$ : $m / z \quad\left[2 \mathrm{M}-\left(\mathrm{PPh}_{3}\right)-2\left(\mathrm{C}_{2} \mathrm{H}_{4}\right)\right]^{+}$obsvd 979 , calcd for $\mathrm{P}_{1} \mathrm{C}_{32} \mathrm{H}_{43} \mathrm{Rh}_{2} \mathrm{~S}_{2} \mathrm{~B}_{18} \mathrm{~N}_{4}$ : 979; [M $\left.\left(\mathrm{C}_{2} \mathrm{H}_{4}\right)\right]^{+}$obsvd 621, calcd for $\mathrm{P}_{1} \mathrm{C}_{25} \mathrm{H}_{29} \mathrm{Rh}_{1} \mathrm{~S}_{1} \mathrm{~B}_{9} \mathrm{~N}_{2}$ : 621. The obsvd isotope envelope matches that calculated from the known isotopic abundances of the constituent elements.

\section{Supplementary material}

CSD-CCDC 1006809 contains the supplementary crystallographic data for this article. Measured and calculated isotopic patterns for compounds $\mathbf{2}$ and $\mathbf{3}$.

\section{Acknowledgments}

We acknowledge the Spanish Ministry of Science and Innovation (CTQ2012-32095, CONSOLIDER INGENIO, CSD2009-00050, MULTICAT and CSD2006-0015, Crystallization Factory) for support of this work and the KFUPM-University of Zaragoza research agreement. B.C. thanks the "Diputación General de Aragón" for a pre-doctoral scholarship.

\section{References}

[1] R.N. Grimes, Comprehensive Organometallic Chemistry, pp. 459-542, in: G. Wilkinson, F.G.A. Stone, E.W. Abel (Eds.), Pergamon Press Ltd., Oxford (1982).

[2] R. Grimes, Metal Interactions with Boron Clusters, pp. 269-319, in: R. Grimes (Ed.) Springer US, (1982).

[3] R.N. Grimes Chem. Rev., 92, 251-268 (1992).

[4] R.N. Grimes, Comprehensive Organometallic Chemistry II, pp. 373-430, in: E.W. Abel, F.G.A. Stone, G. Wilkinson (Eds.), Pergamon, Oxford (1995). 
[5] T.D. McGrath, F.G.A. Stone, Advances in Organometallic Chemistry, Vol 53, pp. 140, in, (2005).

[6] B.E. Hodson, T.D. McGrath, F.G.A. Stone Organometallics, 24, 1638-1646 (2005).

[7] T.D. McGrath, F.G.A. Stone J. Organomet. Chem., 689, 3891-3903 (2004).

[8] D.D. Ellis, P.A. Jelliss, F.G.A. Stone Spec. Publ. - R. Soc. Chem., 253, 291-298 (2000).

[9] P.A. Jelliss, F.G.A. Stone J. Organomet. Chem., 500, 307-323 (1995).

[10] S.A. Brew, F.G.A. Stone Adv. Organomet. Chem., 35, 135-186 (1993).

[11] F.G.A. Stone Adv. Organomet. Chem., 31, 53-89 (1990).

[12] A.K. Saxena, J.A. Maguire, N.S. Hosmane Chem. Rev., 97, 2421-2462 (1997).

[13] A.K. Saxena, N.S. Hosmane Chem. Rev., 93, 1081-1124 (1993).

[14] J.D. Kennedy Prog. Inorg. Chem., 34, 211-434 (1986).

[15] J.D. Kennedy Prog. Inorg. Chem., 32, 519-679 (1984).

[16] L. Barton, Strivastava, D. K., Comprehensive Organometallic Chemistry II, in: E.W. Abel, Stone, F. G. A., Wilkinson, G. (Ed.) Pergamon, New York (1995).

[17] L.T. Todd, Comprehensive Organometallic Chemistry II, pp. 257-273, in: E.W. Abel, F.G.A. Stone, G. Wilkinson (Eds.), Elsevier Science, Oxford (1995).

[18] L.T. Todd, Comprehensive Organometallic Chemistry, pp. 534-553, in: G. Wilkinson, F.G.A. Stone, E.W. Abel (Eds.), Pergamon Press Ltd., Oxford (1982).

[19] L. Wesemann, Comprehensive Organometallic Chemistry, pp. 113-131, in: D.M.P. Mingos, R.H. Crabtree (Eds.), Elsevier, Oxford (2007).

[20] A.S. Weller, Comprehensive Organometallic Chemistry III, pp. 133-174, in: R.H. Crabtree, D.M.P. Mingos (Eds.), Elsevier, Oxford (2007).

[21] G. Ferguson, M.C. Jennings, A.J. Lough, S. Coughlan, T.R. Spalding, J.D. Kennedy, X.L.R. Fontaine, B. Stibr J. Chem. Soc., Chem. Commun., 891-894 (1990).

[22] Á. Álvarez, R. Macías, J. Bould, M.J. Fabra, F.J. Lahoz, L.A. Oro J. Am. Chem. Soc., 130, 2148-2149 (2008).

[23] Á. Álvarez, R. Macías, J. Bould, M.J. Fabra, F.J. Lahoz, L.A. Oro J. Am. Chem. Soc., 130, 11455-11466 (2008).

[24] B. Calvo, R. Macias, V. Polo, M.J. Artigas, F.J. Lahoz, L.A. Oro Chem. Commun., 49, 9863-9865 (2013).

[25] Á. Álvarez, R. Macías, J. Bould, C. Cunchillos, F.J. Lahoz, L.A. Oro Chem. Eur. J., 15, 5428-5431 (2009). 
[26] B. Calvo, R. Macías, M.J. Artigas, F.J. Lahoz, L.A. Oro Chem. Eur. J., 19, 39053912 (2013).

[27] Á. Álvarez, R. Macías, M.J. Fabra, F.J. Lahoz, L.A. Oro J. Am. Chem. Soc., 130, 2148-2149 (2008).

[28] H. Beall, C.H. Bushweller, W.J. Dewkett, M. Grace J. Am. Chem. Soc., 92, 3484$3486(1970)$.

[29] E.G. Kononova, L.A. Leites, S.S. Bukalov, I.V. Pisareva, I.T. Chizhevsky, J.D. Kennedy, J. Bould Eur. J. Inorg. Chem., 2007, 4911-4918 (2007).

[30] K. Nestor, X.L.R. Fontaine, N.N. Greenwood, J.D. Kennedy, J. Plešek, B. Štíbr, M. Thornton-Pett Inorg. Chem., 28, 2219-2221 (1989).

[31] M. Bown, X.L.R. Fontaine, N.N. Greenwood, J.D. Kennedy, M. Thornton-Pett Organometallics, 6, 2254-2255 (1987).

[32] K. Nestor, X.L.R. Fontaine, N.N. Greenwood, J.D. Kennedy, M. Thornton-Pett $J$. Chem. Soc., Chem. Commun., 455-456 (1989).

[33] J. Bould, C. Cunchillos, F.J. Lahoz, L.A. Oro, J.D. Kennedy, R. Macías Inorg. Chem., 49, 7353-7361 (2010).

[34] SAINT-PLUS, version 6.01, Bruker AXS, Inc; Madison, USA (2001).

[35] G.M. Sheldrick, SADABS, University of Göttingen, Göttingen, Germany (1999).

[36] G.M. Sheldrick Acta Cryst., A46, 467-473 (1990).

[37] G.M. Sheldrick Acta Cryst., A64, 112-122 (2008). 